\title{
Cis-dioxo-bis [3-methoxy-2,2-dimethylpropanediamine] Molybdenum/Surfactant-Modified Electrode for Simultaneous Sensing of Ascorbic Acid and Dopamine
}

\author{
Ali Arjmandi, ${ }^{1}$ Hamid Reza Zare-Mehrjardi ${ }^{1,2, *}$ and Hadi Kargar ${ }^{1,2}$ \\ ${ }^{1}$ Department of Chemistry, Payame Noor University, PO BOX 19395-3697 Tehran, Iran \\ ${ }^{2}$ Research Center of Environmental Chemistry, Payame Noor University, Ardakan, Yazd, Iran \\ *Corresponding author: E-mail: hr_zare@pnu.ac.ir,zareanalyst@gmail.com,hr.zaremehr@yahoo.com \\ Tel.: +98 3532220011; fax: +983532228110
}

Received: 20-04-2017

\begin{abstract}
In this work, the carbon paste electrode (CPE) was modified using the cis-dioxo-bis[3-methoxy-2,2-dimethylpropanediamine] molybdenum(VI) complex and 1-octanaminium, $, \mathrm{N}, \mathrm{N}$-trioctyl bromide. Using the modified electrode, the best separation of anodic peaks for ascorbic acid and dopamine was obtained in solutions with $\mathrm{pH} 5.0$ and the linear range for ascorbic acid is acquired in the range from $3.0 \times 10^{-6}$ to $6.0 \times 10^{-3} \mathrm{M}$ and for dopamine from $2.0 \times 10^{-6}$ to 1.0 $\times 10^{-2} \mathrm{M}$. The limits of detection ( $\mathrm{S} / \mathrm{N}=3$ ) were $4 \times 10^{-7} \mathrm{M}$ and $5 \times 10^{-7} \mathrm{M}$ for dopamine and ascorbic acid, respectively. Surface regeneration and the very easy preparation of the modified CPE together with the very good peak resolution and sub-micromolar detection limits designate the prepared carbon paste electrode appropriate for simultaneous voltammetric determination of dopamine and ascorbic acid.
\end{abstract}

Keywords: Dopamine; ascorbic acid; modified electrode; Molybdenum Schiff base complex; differential pulse voltammetry

\section{Introduction}

Recently, the manufacture and design of new voltammetric sensors have been of notable interest. ${ }^{1,2}$ Specially, detection of secretion neurotransmitters, e.g. ascorbic acid (AA) and dopamine (DA) as a vital nutritional factor, through the improvement of the electrochemical sensors received many interests. DA is a significant transmitter of the nervous system and a hormone and is involved in many biological processes in the human brain and body. In the brain, dopamine primarily controls the reward-motivated behavior, while in the body it is involved in processes such as motor control or the release of other important hormones. Low levels of DA are common in those suffering from Parkinson's disease due to the loss of dopamine-containing neurons in the midbrain. Abnormal dopamine concentrations are also related to schizophrenia, attention deficit hyperactivity disorder (ADHD), and restless legs syndrome (RLS). ${ }^{3}$ Dopamine does not pass through the brain-blood barrier, and, in the blood vessels, it serves as a local chemical messenger, like a vasodilator, and reduces insulin production or regulates the activity of lymphocytes. Both - the plant and animal kingdoms contain AA. Among animal organs, anterior pituitary lobe, leukocytes and the liver represent the highest content of AA. Ascorbic acid or vitamin C is not only very popular for its antioxidant properties, but also widely used for the prevention and treatment of the common cold, mental illnesses, infertility, cancers and AIDs. AA is also used in multivitamin preparations and various biological systems. ${ }^{5}$ A serious problem in detection of DA or AA is the overlapping of the anodic peaks of AA and coexisting DA. The anodic oxidation potential of DA is close to that of $A A$ at common solid electrodes and results in the lack of good resolution between their anodic peaks. Several methods have been applied in order to overcome this problem. In recent years, modified carbon paste electrodes have extensively been applied for the determination of DA and AA. For instance, the electrochemical behavior of these biologically important compounds was investigated at the carbon paste electrodes modified with Eriochrome Black $\mathrm{T}$ $(\mathrm{EBT}),{ }^{6}$ reduced graphene oxide, ${ }^{7} \mathrm{~N}$-butylpyridinium hexafluorophosphate, ${ }^{8}$ thionine-nafion ion-paired ${ }^{9}$ and 
thionine-nafion supported on multi-walled carbon nanotube..$^{10}$ Recently, application of carbon nanotubes in the modification of the carbon paste electrodes has performed for detection of DA. ${ }^{11-13}$ Application of nanoparticles, ${ }^{10,11,14-21}$ complexes of transition metals, ${ }^{22-25}$ surfactants, ${ }^{7,15}$ ionic liquids ${ }^{8,12}$ and polymeric materials, ${ }^{23,26}$ in preparation of modified carbon paste electrodes have attracted most consideration in this regard. Using the electron mediators in modification of the electrodes, causes to decrease the overpotential of the electrochemical process of the interested analyte and of course improve the selectivity and sensitivity of the electrode response.

Previous works showed that Schiff base complexes are efficient electron mediators and the oxidation process of different biological compounds, such as AA can be catalyzed using them. ${ }^{27,28}$ The major drawback in the using of redox mediators in the modification of the electrodes is lack of good resolution for simultaneous determination of different analytes in the mixed samples. On the other hand, the application of an electron mediator together with the ionic surfactant in the preparation of modified electrodes, because of the electrostatic repulsion or attraction between the charged analytes and the surfactant, can separate the voltammetric peaks of different compounds and improve the selectivity for their simultaneous detection. Respect to the charge sign of various analytes and the ionic surfactant, the electrostatic interactions can be exclusive or inclusive that is important for the improvement of the voltammetric resolution between the analytes peak. A nafion/reduced graphene oxide prepared film on the surface of carbon electrode has been applied in electrocatalytic oxidation of ascorbic acid. ${ }^{29}$ Modification of carbon paste electrode using an ion pair (thionine/nafion) has been reported. ${ }^{18}$ This electrode has been effective in simultaneous voltammetric determination of AA and DA by DPV. Triton X-100 (as a neutral surfactant) has been applied in preparation of the modified glassy carbon electrode. ${ }^{30}$ Results of this work revealed that the hydrophobicity of the surfactant at the surface of the electrode is effective in promoting the electrochemical response of the studied heme proteins.

In the present work, the electrochemical oxidation of $\mathrm{AA}$ and DA at the surface of the modified carbon paste electrode containing the cis- $\left[\mathrm{Mo}(\mathrm{O})_{2} \mathrm{~L}\right] /$ cationic surfactant is studied. Schiff base complexes are well-known as effective redox mediators and are capable to catalyze the electrochemical oxidation of various organic and biologically important compounds, e.g. ascorbic acid. Of particular interests in this work, are entering of the cationic surfactant into the matrix of the modified electrode and enlargement of the anodic overpotential for DA oxidation. In solutions of $\mathrm{pH} 5.0$, in which all studies are performed, DA exists as the positively charged species. Therefore, the favorable ionic interaction (electrostatic repulsion) between the cationic form of DA and the cationic surfactant $\left(\mathrm{TOA}^{+}\right)$ caused increasing the overvoltage for DA and positive shift in its anodic peak potential. Modification of the carbon paste electrode using the cationic surfactant results in increasing the anodic overpotential for DA oxidation. In order to obtain a higher sensitivity and selectivity in the voltammetric response of the modified electrode, the effect of the cationic surfactant percent on the separation of the anodic peaks of DA and AA is studied. Noteworthy advantages of the modified-CPE described in this paper such as ease of surface regeneration and fabrication, excellent resolution between the anodic peaks of DA and AA and high stability of the cis-[Mo(O) $\left.)_{2} \mathrm{~L}\right]$ and cationic surfactant in its matrix designate it very useful for the sensitive and selective simultaneous detection of DA and AA.

\section{Experimental}

\section{1. Materials}

For the synthesis of the complex cis-dioxo-bis[3-methoxy-2,2-dimethylpropanediamine] molybdenum(VI), a solution of $1 \mathrm{mmol}\left[\mathrm{MoO}_{2}(\mathrm{acac})_{2}\right]$ in $50 \mathrm{~mL}$ methanol was added to the solution of $1 \mathrm{mmol} 3$-methoxy-2,2-dimethylpropanediamine (Schiff base ligand) in $10 \mathrm{~mL}$ methanol and the reaction mixture was stirred for $120 \mathrm{~min}$ at reflux condition. Then the precipitated orange complexes were filtered and washed with methanol. ${ }^{31}$ For to the preparation of CPEs, spectroscopic mineral oil (Nujol), graphite powder $(20 \mu \mathrm{m})$, and 1-octanaminium,N,N,N-trioctyl bromide as a cationic surfactant were purchased from Merck. All the other chemicals were analytical reagent grade, purchased from Merck. Using bidistilled deionized water, all aqueous solutions were made up.

Stock solutions of DA and AA were freshly made up in a buffered solution and before voltammetric experiments, purged with pure nitrogen gas (99.999\%) for $120 \mathrm{~s}$. The buffered solutions of DA and AA were deoxygenated by purging the pure nitrogen $(99.999 \%$ from Roham Gas Company) before use for voltammetric studies. Nitrogen gas was passed over the surface of the test solutions during the measurements, in order to avoid the influx of oxygen into the solution.

For the determination of the recovery in spiking of dopamine, the sample of fresh human serum, prepared from Razi Institute of Vaccine and Serum Co. (Tehran, Iran), was filtered and diluted using a $0.1 \mathrm{M}$ acetate buffer solution of $\mathrm{pH}$ 5.0. Each tablet was grounded with a mortar and pestle to detect AA in commercial vitamin preparation, then $100 \mathrm{mg}$ of the powdered sample was dissolved in $100 \mathrm{~mL}$ of the buffered solution.

\section{2. Apparatus}

In order to make up the buffered solutions, a digital $\mathrm{pH} / \mathrm{mV} /$ ion meter (CyberScan model 2500) was used. A common three-electrode system was applied with a platinum wire as a counter electrode, a saturated Calomel ref- 
erence electrode, and modified or unmodified carbon paste working electrode. Voltammetric measurements were performed using a computerized potentiostat/galvanostat Autolab model 302 (Eco Chemie Utrecht) controlled with General Purpose Electrochemical System (GPES) software.

\section{3. Preparation of the Carbon Paste Electrodes}

To prepare the unmodified CPE, a suitable amount of mineral oil with powder of graphite $(\sim 25: 75, w / w)$ was mixed by hand mixing in a mortar and pestle, then a portion of the resulted mixture was packed into the end of a polyamide tube (ca. $2.5 \mathrm{~mm}$ i.d.). A copper pin makes the electrical contact into the back of the composite, in the polyamide tube. The cis- $\left[\mathrm{Mo}(\mathrm{O})_{2} \mathrm{~L}\right]$-modified carbon paste electrode was fabricated by mixing the cis- $\left[\mathrm{Mo}(\mathrm{O})_{2} \mathrm{~L}\right](3 \%$, $\mathrm{w} / \mathrm{w}$ ) with powder of graphite and a suitable amount of mineral oil, and then the resulted composite was dissolved in dichloromethane in order to achieve better homogeneity and reproducibility by polishing the electrode surface. For fabrication of the cis-[Mo(O) $\left.)_{2} \mathrm{~L}\right]$-modified carbon paste electrode containing surfactant, various percents of cationic surfactant together with 3 wt.\% cis- $\left[\mathrm{Mo}(\mathrm{O})_{2} \mathrm{~L}\right]$, powder of graphite and a suitable amount of mineral oil were mixed in an appropriate amount of dichloromethane. The solvent of the resulted mixture has been evaporated completely by stirring, and then air dried for one day and packed into the end of a polyamide tube.

\section{Results and Discussion}

\section{1. Voltammetric Experiments of AA and DA at the Prepared Electrodes}

Our previous work revealed that anodic overpotential for ascorbic acid oxidation is reduced and its oxidation process is catalyzed by Schiff base complexes. ${ }^{17}$ The electrochemical behavior of $1 \mathrm{mM}$ AA in a buffered solution of $\mathrm{pH} 5.0$ at the surface of the unmodified CPE and the cis- $\left[\mathrm{Mo}(\mathrm{O})_{2} \mathrm{~L}\right]$-modified $\mathrm{CPE}$ containing various wt.\% of cationic surfactant is studied by cyclic voltammetry. Results of this study are shown in Figure 1A. As can be observed, at the surface of the unmodified carbon paste electrode, a relatively broad wave in $470 \mathrm{mV}$ appeared for the anodic oxidation of AA. But, by introducing the cis- $\left[\mathrm{Mo}(\mathrm{O})_{2} \mathrm{~L}\right]$ in the matrix of the carbon paste electrode $\left(\right.$ cis- $\left.\left[\mathrm{Mo}(\mathrm{O})_{2} \mathrm{~L}\right] / \mathrm{CPE}\right)$, the anodic oxidation potential of AA decreased to about $435 \mathrm{mV}$. At the surface of modified electrodes including cis-[Mo(O) $\left.)_{2} \mathrm{~L}\right]$ and different wt.\% of cationic surfactant, this overpotential is slightly decreased with increasing the amount of surfactant in the matrix of the electrode. A comprehensive explanation of the electrocatalytic oxidation of AA using the $c i s-\left[\mathrm{Mo}(\mathrm{O})_{2} \mathrm{~L}\right] / \mathrm{CPE}$ is presented in the following. AA, with a $\mathrm{p} K_{\mathrm{a}}$ of 4.17 , mainly exists as an anionic form (ascorbate, below scheme) under the experimental condition (buffered solution with $\mathrm{pH}$ 5.0). Therefore, there is an electrostatic interaction between the anionic form of AA and the cationic surfactant on the surface of the modified-CPE including cationic surfactant $\left(\right.$ cis- $\left.\left[\mathrm{Mo}(\mathrm{O})_{2} \mathrm{~L}\right] / \mathrm{CS} / \mathrm{CPE}\right)$. Results of this investigation reveal that the higher percents of cationic surfactant, because of decreasing the electrical conductivity of the electrode and unsuitable mechanical properties, result in worsening the voltammetric response of the modified-CPE, e.g. enlargement of the capacitive background current, broadening the wave shape and lowering the anodic peak. Hence, the percent of cationic surfactant in the matrix of the modified-CPE is optimized to obtain the excellent resolution between the voltammetric responses of $\mathrm{DA}$ and $\mathrm{AA}$ and also, higher sensitivity in voltammetric peaks (lower background current and greater anodic peak current).
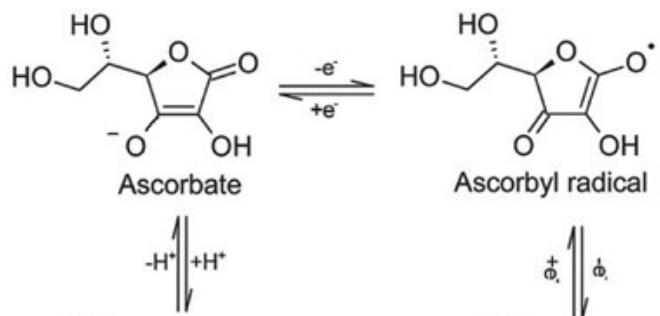

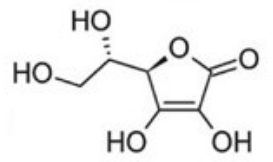

Ascorbic acid

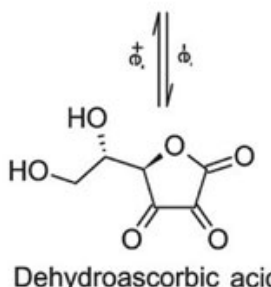

Dehydroascorbic acid
Scheme 1. Ionization of ascorbic acid followed by the oxidation-reduction reactions of ascorbate ions under the experimental condition (buffered solution with $\mathrm{pH}$ 5.0).

The electrochemical behavior of $1 \mathrm{mM} \mathrm{DA}$ in a buffered solution of $\mathrm{pH} 5.0$ at the surface of the unmodified $\mathrm{CPE}$ and the cis-[Mo(O) $\left.{ }_{2} \mathrm{~L}\right]$-modified carbon paste electrode containing various wt.\% of cationic surfactant is studied by cyclic voltammetric method. The results of this study are shown in Figure 1B. A pair of redox peaks with anodic and cathodic peak potentials respectively, 608 and $332 \mathrm{mV}\left(\Delta E_{\mathrm{p}}=276 \mathrm{mV}\right)$ and the ratio of cathodic to anodic peak current $\left(I_{\mathrm{p}, \mathrm{c}} / I_{\mathrm{p}, \mathrm{a}}\right)$ nearly 0.88 were acquired for DA at unmodified carbon paste electrode (CPE). As a result, at the surface of CPE, the electrochemical process of DA is quasi-reversible and the oxidation product of DA under the empirical conditions ( $\mathrm{pH} \mathrm{5.0)}$ is relatively stable.

Previous studies revealed that oxidation product of DA (dopaminequinone) performed an intramolecular 1,4-Michael addition in solutions with higher $\mathrm{pHs}^{32}$ that in this reaction, a nucleophilic attack of external amine group on dopaminequinone leads to leucodopaminochrome. Thus buffered solution of $\mathrm{pH} 5.0$ was selected for 
(A)

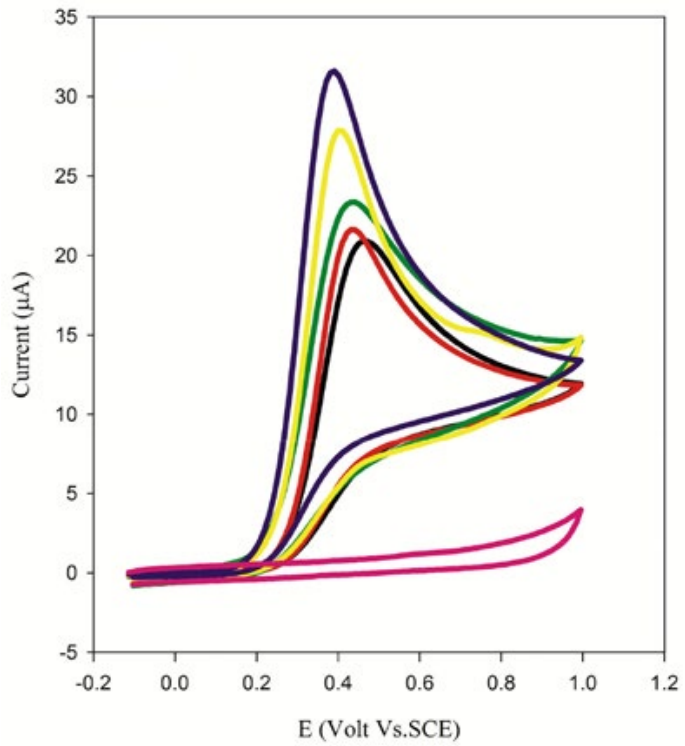

(B)

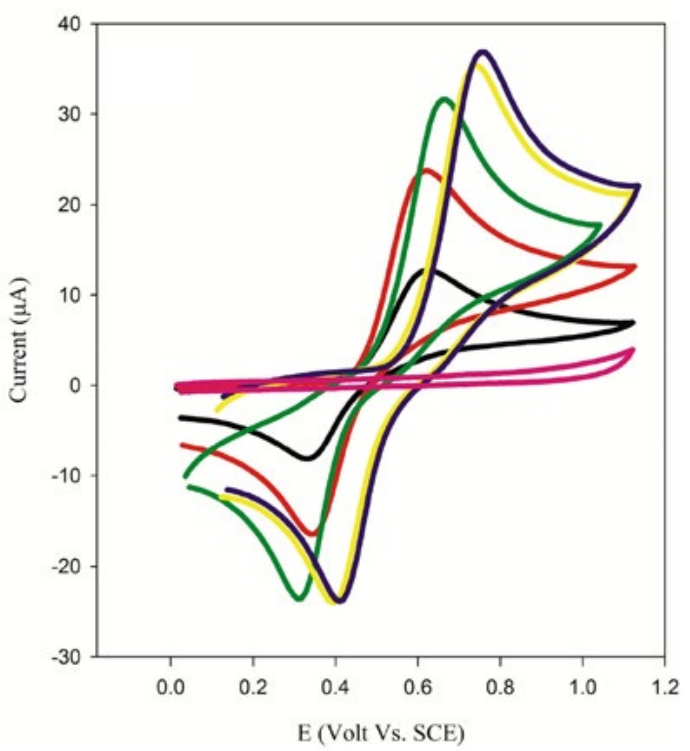

Figure 1. CV responses of blank buffered solution of $\mathrm{pH} 5.0$ using cis- $\left[\mathrm{Mo}(\mathrm{O})_{2} \mathrm{~L}\right] /$ modified CPE containing $2 \% \mathrm{CS}$ (pink) and of $1 \mathrm{mM}$ $\mathrm{AA}(\mathrm{A})$ and $1 \mathrm{mM} \mathrm{DA}(\mathrm{B})$ in the same buffer at the surface of unmodified CPE (black), CoL/modified CPE containing 0\% (red), $1 \%$ (green), 2\% (yellow) and 3\% CS (dark blue). Sweep rate: $100 \mathrm{mVs}^{-1}$; pulse amplitude: $50 \mathrm{mV}$.

all experiments of DA in order to obtain a simple electron transfer and prevent the following reactions for DA. In fact, in solutions of $\mathrm{pH} \leq 5$, DA contains protonated amine group and mostly exists in cationic form. Hence, the product of anodic oxidation of DA in acidic solutions will be almost stable and can be about 1.0 for ratio of $I_{\mathrm{p}, \mathrm{c}} / I_{\mathrm{p}, \mathrm{a}}$.

Application of the cationic surfactant in the preparation of the modified-CPE causes an increase in anodic overpotential of DA oxidation, because of the electrostatic interaction at the surface of the modified electrode between the positive charge of cationic surfactant and the cationic form of DA. As a result, the reversibility of the electrochemical process of DA at the surface of the electrode is decreased $\left(\Delta E_{\mathrm{p}}\right.$ is increases) and its overpotential for oxidation is increased. As can be seen in Figure 1B by increasing the percent of cationic surfactant in the modified carbon paste electrode, this effect is intensified. The result of this effect is excellent resolution between the anodic peaks of AA and DA.

\section{2. Voltammetric Experiments in the Mixed Solutions of DA and AA}

Making an approach for separation of anodic peaks and simultaneous detection of AA and DA is very important with respect to mutual quantification. At the traditional solid electrodes, the anodic overpotential for oxidation of AA is the same as that of DA; furthermore, both of AA and DA are present simultaneously in mammalian brain which will cause to overlap the voltammetric responses of these species. ${ }^{33}$ Many efforts have been made on the fabrication of the modified electrodes that are capable to separate their anodic peaks and make the feasibility of simultaneous determination of DA and AA. ${ }^{21-26}$

In this work, cis- $\left[\mathrm{Mo}(\mathrm{O})_{2} \mathrm{~L}\right]$-modified $\mathrm{CPE}$ containing cationic surfactant was used for simultaneous voltammetric detection of these compounds. The electrochemical behavior of $1 \mathrm{mM}$ of both DA and AA in a buffered solution of $\mathrm{pH} 5.0$ at the surface of the unmodified CPE and the cis- $\left[\mathrm{Mo}(\mathrm{O})_{2} \mathrm{~L}\right]$-modified carbon paste electrode containing various wt.\% of cationic surfactant was studied by cyclic voltammetric method. The results of this study are shown in Figure 2A. Figure 2B shows the differential pulse voltammograms (DPVs) of five prepared electrodes in this solution. These figures revealed that at the surface of the unmodified CPE, only a quasi-reversible wave can be observed for DA and a distinguished wave cannot be obtained for $\mathrm{AA}$, therefore this electrode (unmodified-CPE) isn't suitable for the simultaneous voltammetric detection of DA and AA. By introducing the cis- $\left[\mathrm{Mo}(\mathrm{O})_{2} \mathrm{~L}\right]$ in the matrix of carbon paste electrode (cis- $\left.\left[\mathrm{Mo}(\mathrm{O})_{2} \mathrm{~L}\right] / \mathrm{CPE}\right)$, a little resolution between anodic peaks of DA and AA is obtained but the detection of each compound in the presence of the other isn't possible because of the overlapping of their anodic peaks. Application of cis- $\left[\mathrm{Mo}(\mathrm{O})_{2} \mathrm{~L}\right]$-modified $\mathrm{CPE}$ containing cationic surfactant, results in better resolution of anodic peaks for DA and AA, because of positive shift of DA anodic peak. As can be seen in Figure 2, at the modified-CPE including 2 wt.\% of cationic surfactant, the complete resolution between anodic peaks of DA and AA is obtained. The positive shift in anodic peak potentials of DA under the experimental condition (buffered solution of $\mathrm{pH}$ 5.0) is a result of the electrostatic repulsion effects between the cationic surfactant and cationic form of dopamine. A better resolution does not obtained by using higher percents of cationic surfactant, whereas the sensitivity of electrode response to DA is decreased because of the resulted anodic overpotential and kinetic limitation for DA. More- 
over, this investigation revealed that applied higher percents of cationic surfactant in modification of the electrode caused to limit the voltammetric detection limit for DA and AA (increase the capacitive background current). These efficacies can be obviously seen by comparing of the CVs or DPVs for the different modified CPEs in Figure 2. As a result, the cis-[Mo(O) $\left.{ }_{2} \mathrm{~L}\right]$-modified $\mathrm{CPE}$ containing 2 wt.\% cationic surfactant was selected for simultaneous detection of DA and AA.

The resulting resolution between the anodic peaks of $\mathrm{DA}$ and $\mathrm{AA}$ in this investigation $(308 \mathrm{mV})$ is significantly more desirable than other reported voltammetric sensors. The modified electrode with nanocomposite of carbon

(A)

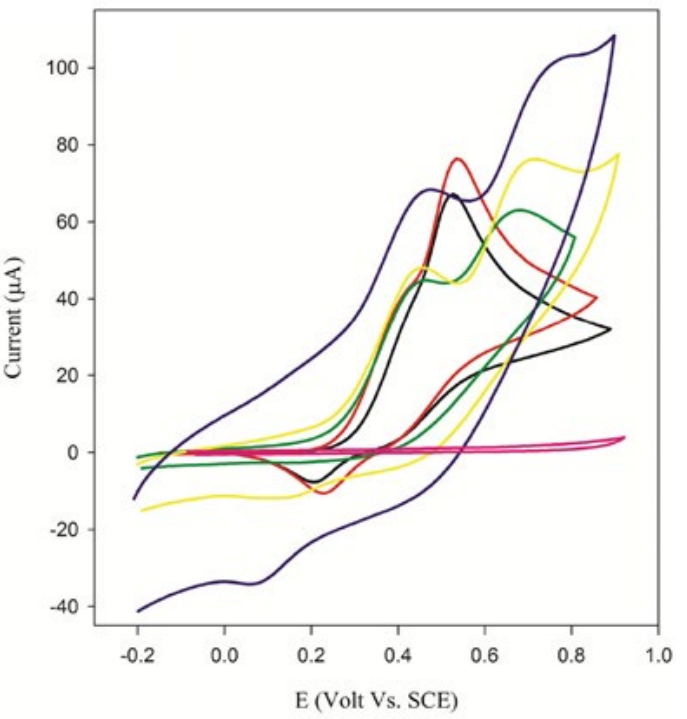

(B)

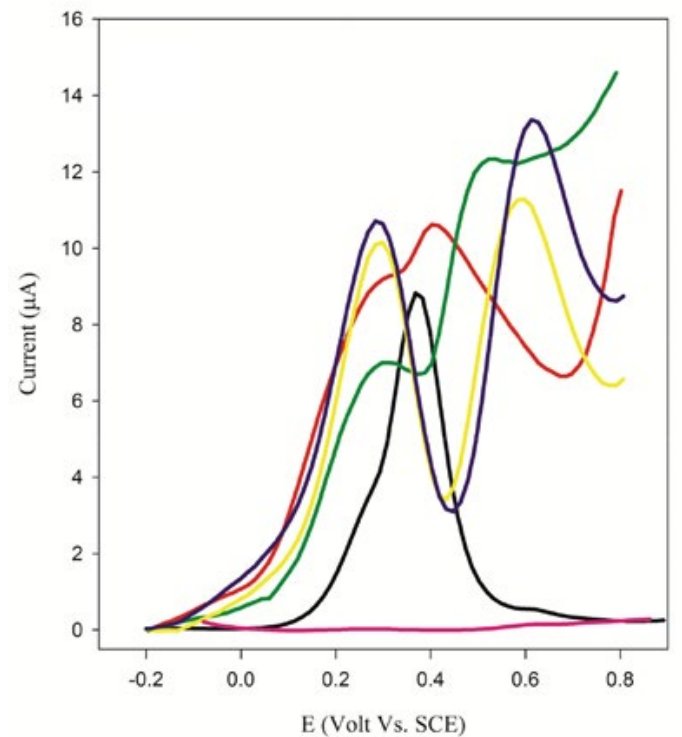

Figure 2. (A) CV and (B) DPV responses of blank buffered solution of $\mathrm{pH} 5.0$ using cis- $\left[\mathrm{Mo}(\mathrm{O})_{2} \mathrm{~L}\right] /$ modified $\mathrm{CPE}$ containing $2 \% \mathrm{CS}$ (pink) and of a mixture of $1 \mathrm{mM} \mathrm{DA}$ and $1 \mathrm{mM} \mathrm{AA}$ in the same buffer at the surface of unmodified CPE (black), CoL/modified CPE containing $0 \%$ (red), 1\% (green), 2\% (yellow) and 3\% CS (dark blue). Sweep rate: $100 \mathrm{mVs}^{-1}$; pulse amplitude: $50 \mathrm{mV}$. dots/ferrocene derivative functional Au NPs and graphene obtained a peak resolution for DA and AA about $180 \mathrm{mV}$ using differential pulse voltammetry. ${ }^{34}$ Application of a nanocomposite containing polypyrrole/ $\mathrm{Cu}_{\mathrm{x}} \mathrm{O}-\mathrm{ZnO}$ in modification of the electrode for voltammetric detection of AA and DA resulted in a peak separation of $150 \mathrm{mV}^{35}$ The electrode modified with nanoparticles of $\gamma-\mathrm{WO}_{3}$ is applied using DPV for simultaneous detection of AA and DA and a peak resolution of $133 \mathrm{mV}$ is obtained. ${ }^{36}$ In comparison to the previous works, the decay of anodic current between the anodic peaks of DA and AA is taken place close to the capacitive background by using the cis- $\left[\mathrm{Mo}(\mathrm{O})_{2} \mathrm{~L}\right]$-modified $\mathrm{CPE}$ containing cationic surfactant. The resulted decay of current significantly causes to decrease the overlapping of the anodic waves of DA and $\mathrm{AA}$, and simultaneous detection of these compounds in mixture samples possesses a more desirable accuracy. Moreover the reproducibility of the detections is improved, due to better stability of DA and AA in slightly acidic condition ( $\mathrm{pH}$ 5.0).

\section{3. The Effect of $\mathbf{p H}$ and Sweep Rate}

Voltammetric studies of the buffered solutions with different $\mathrm{pHs}$ containing AA and DA were carried out to find out the optimized $\mathrm{pH}$ for acquiring the good sensitivity and an excellent resolution between their anodic peaks. In these experiments, $0.1 \mathrm{M}$ phosphate was applied in preparation of buffered solutions of $\mathrm{pH} 3.0,6.0$ and 7.0, and $0.1 \mathrm{M}$ acetate for $\mathrm{pHs} 4.0$ and 5.0. Table 1 shows the peak potentials and peak currents of cyclic voltammograms obtained at the surface modified CPE in the mixture solutions of DA and AA with different $\mathrm{pHs}$. These results reveal that the best peak separation is resulted in $\mathrm{pH}$ 5.0. Therefore, in all voltammetric studies, the buffered solution with $\mathrm{pH} 5.0$ was applied as supporting electrolyte.

In order to investigate the effect of the potential scan rate, cyclic voltammetric experiments were carried out in the buffered solution with $\mathrm{pH}$ 5.0. The results revealed that the anodic peak currents $\left(I_{\mathrm{p}, \mathrm{a}}\right)$ of DA and AA increase linearly with increasing the square root of the scan rate $\left(v^{1 / 2}\right)$ in the range of $25-200 \mathrm{mVs}^{-1}$. These results corroborate the diffusion-controlled anodic oxidation of DA and AA at

Table 1. Variation of peak potential and peak current of cyclic voltammograms for mixture solutions of DA and AA with different $\mathrm{pH}$ using $c i s-\left[\mathrm{Mo}(\mathrm{O})_{2} \mathrm{~L}\right] /$ modified $\mathrm{CPE}$ containing $2 \mathrm{wt}$ \% of cationic surfactant

\begin{tabular}{|c|c|c|c|c|c|}
\hline \multirow[t]{2}{*}{ pH } & \multicolumn{2}{|c|}{$\mathbf{A A}$} & \multicolumn{2}{|c|}{ DA } & \multirow{2}{*}{$\Delta \mathrm{E}_{\mathrm{p}}$} \\
\hline & $I_{p, a}(\mu \mathbf{A})$ & $\mathrm{E}_{\mathrm{p}, \mathrm{a}}(\mathrm{mV})$ & $I_{p, a}(\mu \mathbf{A})$ & $\mathrm{E}_{\mathrm{p}, \mathrm{a}}(\mathrm{mV})$ & \\
\hline 3 & 24.2 & 458 & 23.6 & 731 & 273 \\
\hline 4 & 19.9 & 421 & 22.5 & 722 & 301 \\
\hline 5 & 22.5 & 395 & 25.3 & 710 & 315 \\
\hline 6 & 18.8 & 391 & 23.8 & 679 & 288 \\
\hline 7 & 16.5 & 387 & 23.3 & 668 & 281 \\
\hline
\end{tabular}


the prepared CPE surface. The current function $\left(I_{\mathrm{p}} / v^{1 / 2}\right)$ for AA decreased with $v^{1 / 2}$, which corroborates a catalytic manner for AA at the surface of the modified CPE, whereas for DA this effect can't be seen.

\section{4. Analytical Characterization}

The differential pulse voltammetric method using the cis- $\left[\mathrm{Mo}(\mathrm{O})_{2} \mathrm{~L}\right]$-modified CPE containing $2 \mathrm{wt}$ \% of cationic surfactant was applied as a useful approach with low
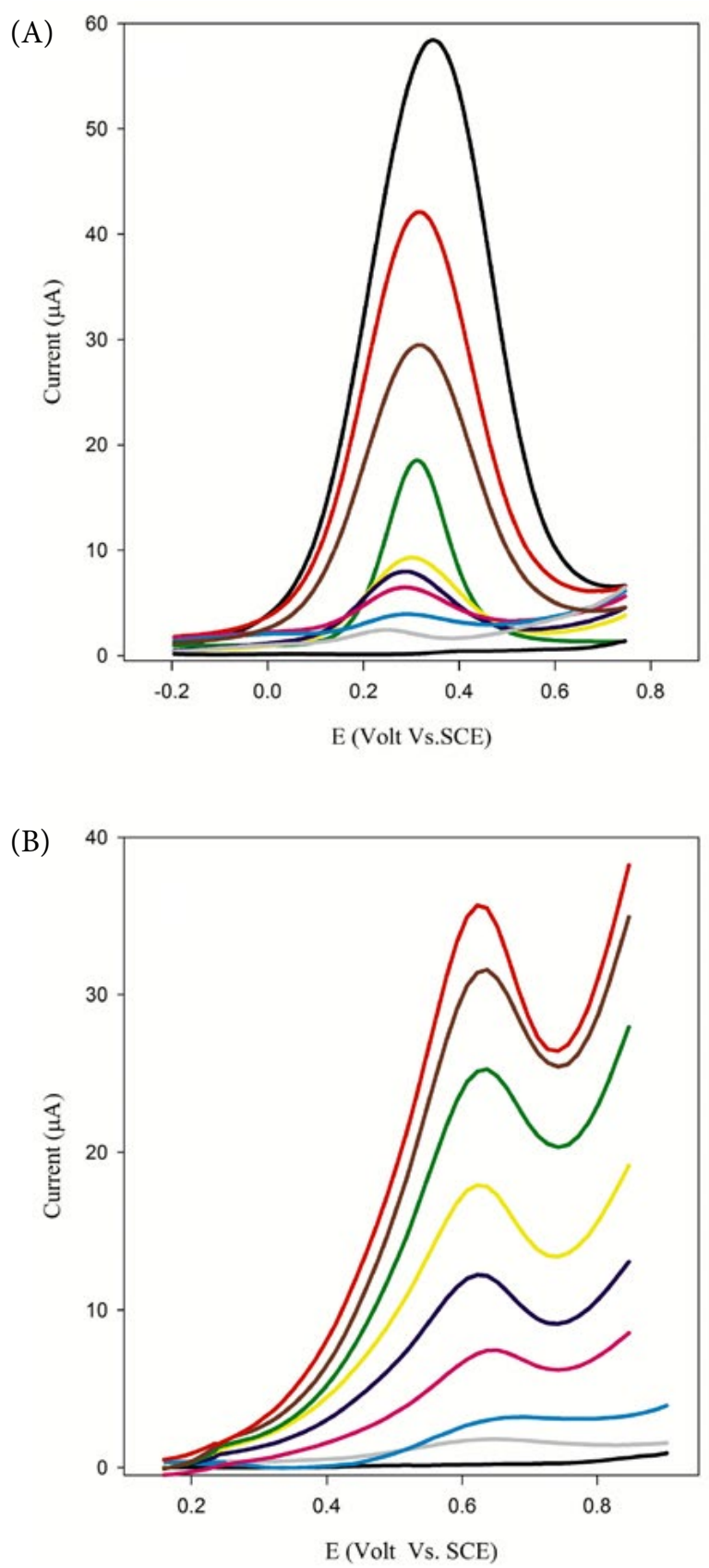

Figure 3. Differential pulse voltammograms of buffered solution of pH 5.0 containing (A) 0.0, 0.1, 0.2, 0.5, 0.8, 1.0, 2.0, 3.0, 4.0, 5.6 and $6.0 \mathrm{mM}$ AA and (B) $0.0,0.2,0.3,0.5,0.9,1.0,1.2,1.6,2.2$ and 2.5 $\mathrm{mM}$ DA (down to up). Pulse amplitude: $50 \mathrm{mV}$. limits of detection for detections of DA and AA in a wide range of their concentrations. Supporting electrolyte for these experiments was buffered solutions of $\mathrm{pH}$ 5.0. Figure 3 shows some obtained DPV waves in these experiments. By drawing the anodic current signal versus the concentration (the calibration curves), a linear range is obtained that is $2.0 \times 10^{-6}-1.0 \times 10^{-2} \mathrm{M}$ for DA and $3.0 \times 10^{-6}-6.0 \times$ $10^{-3} \mathrm{M}$ for AA (Figure 4). A slope of $9355.75 \mu \mathrm{A} / \mathrm{M}\left(R^{2}=\right.$ $0.9985)$ is resulted for AA, and a slope of $6534.37 \mu \mathrm{A} / \mathrm{M}$ $\left(R^{2}=0.9986\right)$ for DA. The relative standard deviations (R.S.D.) for these slopes on the basis of five replicates were 3.4 and $3.1 \%$ for DA and AA, respectively and were less than 3.5\% for both DA and AA, based on seven measurements in a period of two months. So the prepared modified CPE in this work revealed to be very stable.

The differential pulse voltammograms obtained in solutions containing $5 \times 10^{-4} \mathrm{M} \mathrm{AA}$ and five various amounts of DA from $4 \times 10^{-4}$ to $2 \times 10^{-3} \mathrm{M}$ are shown in Figure 5A. The waves obtained in solutions including $5 \times$ $10^{-5} \mathrm{M} \mathrm{DA}$ and various amounts of AA in the range of $5 \times$ $10^{-5}$ to $9 \times 10^{-4} \mathrm{M}$ is represented in Figure $5 \mathrm{~B}$. Using the modified CPE in this work, a linear range for AA in buffered solutions of $\mathrm{pH} 5.0$ is acquired in the range from 4.0 $\times 10^{-6}-7.0 \times 10^{-3} \mathrm{M}$ and for DA from $2.0 \times 10^{-6}-9.0 \times 10^{-3}$ M. The respective limits of detection $(\mathrm{S} / \mathrm{N}=3)$ were $4 \times$ $10^{-7} \mathrm{M}$ and $5 \times 10^{-7} \mathrm{M}$ for DA and AA, respectively. The resulted limits of detection and linear ranges were very similar to the detections in solutions containing only one of DA or AA. In the presence of $5 \times 10^{-4} \mathrm{M} \mathrm{AA}$, the calibration curve slope for DA was $6403.68 \mu \mathrm{A} / \mathrm{M}\left(R^{2}=0.9985\right)$, which was about $98 \%$ of the resulted slope value for the separate DA solutions. This slope for AA, in the presence of $5 \times 10^{-5} \mathrm{M}$ DA was $9075.08 \mu \mathrm{A} / \mathrm{M}\left(R^{2}=0.9978\right)$.

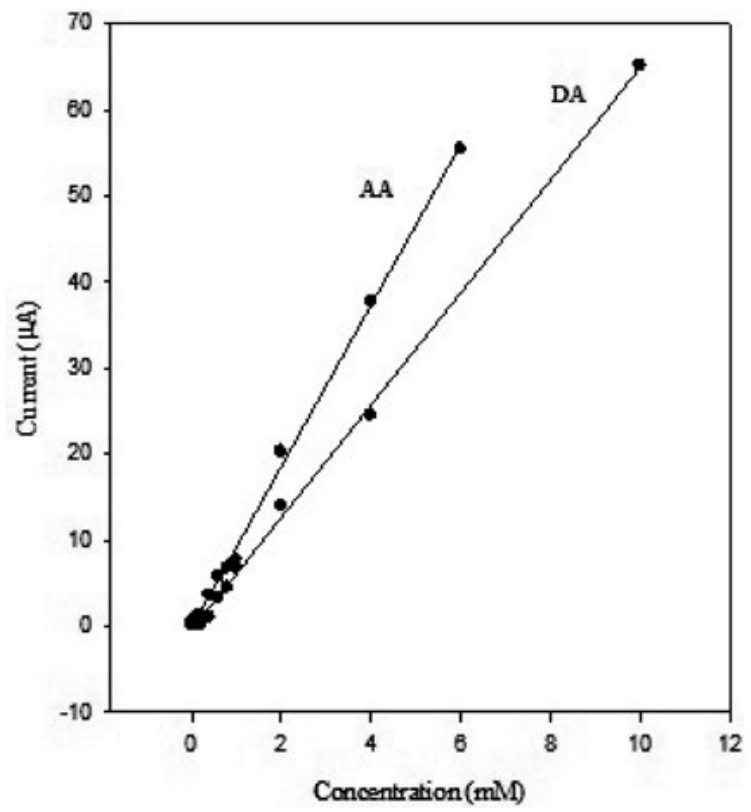

Figure 4. Linear calibration curves of current signals versus DA and AA concentration in the range 10.0 to $1000.0 \mu \mathrm{M}$. 

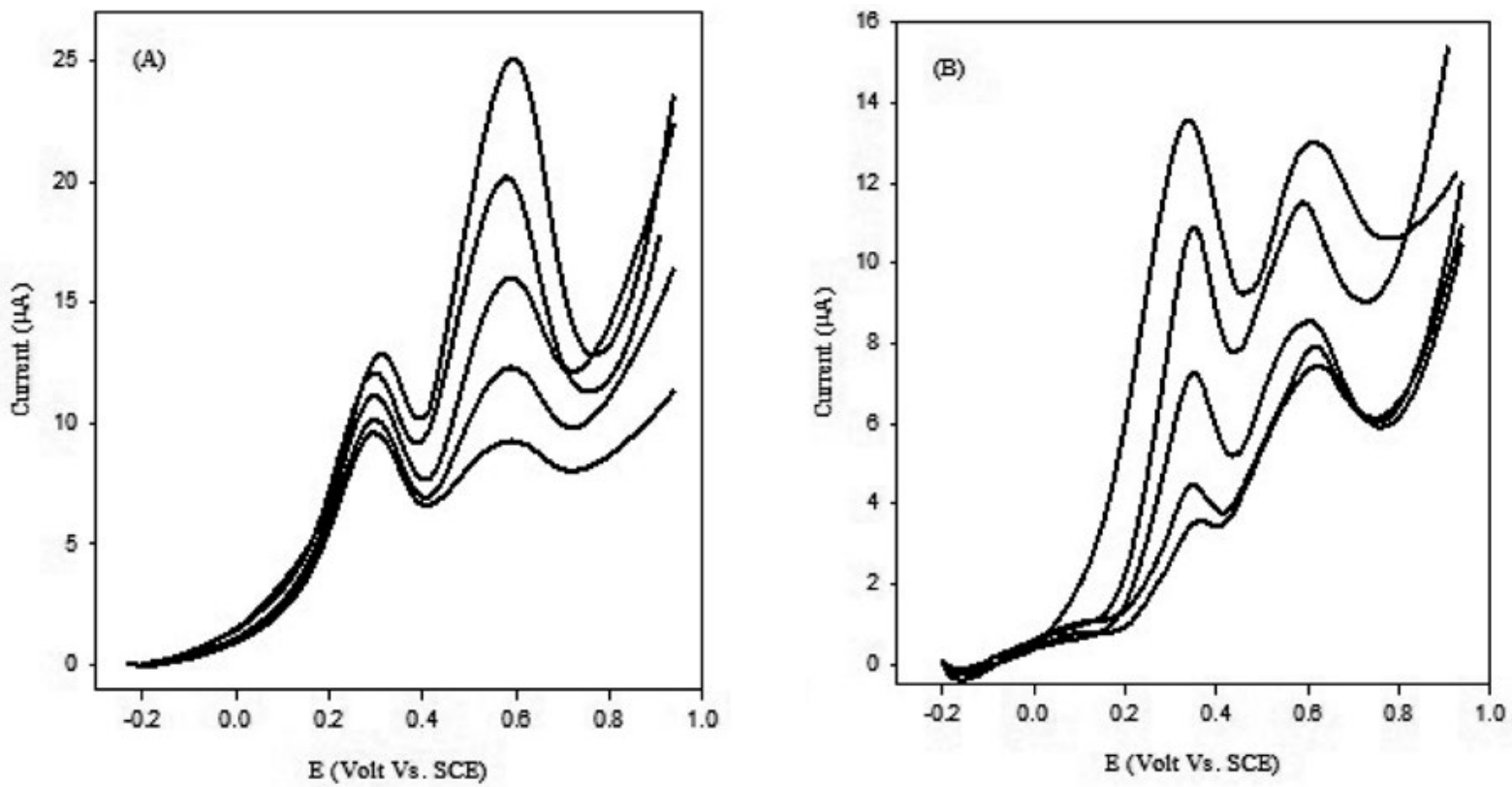

Figure 5. Differential pulse voltammograms for buffered solution of $\mathrm{pH} 5.0$ containing (A) $0.5 \mathrm{mM} \mathrm{AA}$ (constant) and various concentrations of DA: $0.4,0.7,1.0,1.6,2.0 \mathrm{mM}$. (B) $0.5 \mathrm{mM}$ DA (constant) and various concentrations of AA: $0.05,0.1,0.5,0.7,0.8$ and $0.9 \mathrm{mM}$. Pulse amplitude: $50 \mathrm{mV}$.

Table 2. AA analysis results in vitamin preparations using cis- $\left[\mathrm{Mo}(\mathrm{O})_{2} \mathrm{~L}\right] /$ modified CPE containing $2 \mathrm{wt}$ \% of cationic surfactant

\begin{tabular}{|c|c|c|c|c|}
\hline \multirow[t]{2}{*}{ Sample } & \multirow[t]{2}{*}{ Added AA (mg) } & \multicolumn{3}{|c|}{ AA found (mg/100 mg sample) } \\
\hline & & Present method & Reference method & Recovery (\%) \\
\hline \multirow[t]{4}{*}{ Multivitamin drop ${ }^{\mathrm{b}}$} & & $36.3( \pm 1.5)$ & 37.0 & - \\
\hline & 10.0 & $45.4( \pm 1.8)$ & - & 98.0 \\
\hline & 20.0 & $54.1( \pm 1.9)$ & - & 96.1 \\
\hline & 30.0 & $68.1( \pm 1.9)$ & - & 102.7 \\
\hline \multirow[t]{4}{*}{ Vitamin $\mathrm{C}$ tablet } & & $66.6( \pm 1.7)$ & 67.1 & - \\
\hline & 10.0 & $77.5( \pm 1.9)$ & - & 101.1 \\
\hline & 20.0 & $85.2( \pm 2.0)$ & - & 98.4 \\
\hline & 30.0 & $99.6( \pm 2.1)$ & - & 103.1 \\
\hline
\end{tabular}

${ }^{a}$ Replicates Number was five. ${ }^{b}$ Labeled AA value was $35 \mathrm{mg} / \mathrm{mL}$. Determined values are also in $\mathrm{mg} / \mathrm{mL}$.

In order to investigate the selectivity of the modified electrode for simultaneous determination of DA and AA, several potential interfering compounds were selected and checked. It is found that 100 -fold $\mathrm{K}^{+}, \mathrm{Na}^{+}, \mathrm{Ca}^{2+}, \mathrm{Mg}^{2+}, \mathrm{Zn}^{2+}$, $\mathrm{Cu}^{2+}, \mathrm{Fe}^{3+}, \mathrm{NH}_{4}^{+}, \mathrm{Cl}^{-}, \mathrm{NO}_{3}^{-}, \mathrm{SO}_{4}^{2-}$, and $\mathrm{HCO}_{3}^{-}$did not interfere with determination (signal change $<5 \%$ ). In the case of coexisting biological compounds such as glucose, fructose, sucrose, lactose, cysteine, epinephrine, acetaminophen, and serotonin, 100-fold of them did not interfere. So, it may be concluded that the method is free from interference by most coexisting substances and shows promising properties for use in real samples with minimal sample preparation. The cis-[Mo(O) $\left.)_{2} \mathrm{~L}\right]$-modified CPE containing 2 wt.\% of cationic surfactant was successfully used for determination of AA in pharmaceutical preparations through the standard addition method. The analyzed vitamin preparations were effervescent tablets (Osvah Co.), multivitamin drops (Shahre Daro Co.) and vitamin C tablets (Osvah Co.). In addition to vitamin C, the multivita- min drops contained sodium saccharin and vitamins such as $\mathrm{A}, \mathrm{D}, \mathrm{E}, \mathrm{B}_{1}, \mathrm{~B}_{2}, \mathrm{~B}_{3}, \mathrm{~B}_{6}$, and $\mathrm{B}_{12}$. As a reference method, the method of U.S. Association of Official Analytical Chemists $(\mathrm{AOAC})^{37}$ on the basis of using 2,6-dichloro-phenolindophenol was used. Table 2 shows the results of the experiments in different samples of vitamin and the results of

Table 3. Recovery results of the spiked DA to $10.0 \mathrm{~mL}$ of the diluted (10-fold) human serum sample

\begin{tabular}{cccc}
\hline No. & $\begin{array}{c}\text { added DA } \\
(\boldsymbol{\mu M})\end{array}$ & $\begin{array}{c}\text { Amounts of found } \\
\text { DA }(\boldsymbol{\mu M})\end{array}$ & $\begin{array}{c}\text { Recovery } \\
(\%)\end{array}$ \\
\hline 1 & 10.0 & 9.8 & 98.0 \\
2 & 25.0 & 24.6 & 98.4 \\
3 & 50.0 & 50.7 & 101.4 \\
4 & 75.0 & 76.5 & 102.0 \\
5 & 100 & 98.2 & 98.2 \\
\hline
\end{tabular}

${ }^{a}$ For five replicates in the spiked range of DA concentration, R.S.D. was less than $3.7 \%$. 
the spiked samples with AA standard solutions. These results reveal that the prepared electrode could be successfully used for the detection of AA in pharmaceutical samples because of the good enough precision and recovery. This modified electrode was also used for the recovery measurement in dopamine hydrochloride spiking to human serum samples. The results of these experiments are shown in Table 3.

\section{Conclusion}

The cis- $\left[\mathrm{Mo}(\mathrm{O})_{2} \mathrm{~L}\right]$-modified CPE containing cationic surfactant prepared in the present work can enhance the selectivity and resolution of voltammetric responses of DA and AA. This modified CPE has been revealed to be capable to separate the anodic peaks of DA and AA. Resulted resolution is much better than in the previous reported works. Table 4 shows a comparison of analytical properties for the detection of DA and AA at the prepared electrode in this work and various other electrodes.
Application of the modified CPE in differential pulse voltammetric method in this work, results in a good resolution more than $300 \mathrm{mV}$ for anodic peaks of AA and DA making it very appropriate and efficient for simultaneous detection of these compounds. Surface regeneration and very easy preparation of the modified electrode together with the acceptable selectivity and sensitivity, and good reproducibility of the voltammetric response proved the potential of the electrode. The resulted detection limit was appropriate but higher than some other works in literature. These results represent the prepared modified system is very effective in the fabrication of accessible tools for the simultaneous detection of DA and AA in pharmaceutical and clinical preparations.

\section{Acknowledgement}

The authors gratefully acknowledge the Payame Noor University providing research facilities for this work.

Table 4. Various modified electrodes: DA and AA analytical properties

\begin{tabular}{|c|c|c|c|c|c|c|c|c|}
\hline \multirow{2}{*}{ Electrode } & \multirow{2}{*}{$\begin{array}{l}\text { Experimental } \\
\text { condition }\end{array}$} & \multirow{2}{*}{ Method } & \multirow{2}{*}{$\Delta E_{p}(\mathrm{mV})$} & \multicolumn{2}{|c|}{ Linear range $(\mu \mathrm{M})$} & \multicolumn{2}{|c|}{ LOD $(\mu \mathrm{M})$} & \multirow{2}{*}{ Ref. } \\
\hline & & & & DA & AA & DA & $\mathbf{A A}$ & \\
\hline EBT/CPE & $0.1 \mathrm{M} \mathrm{KCl}$ & DPV & 163 & $10.0-70.0$ & - & 0.18 & 0.27 & 6 \\
\hline $\begin{array}{l}\mathrm{SDS} / \mathrm{RGO} / \\
\mathrm{CPE}\end{array}$ & $\begin{array}{c}\text { pH } 7.4 \\
\text { PBS }\end{array}$ & DPV & 178 & $0.5-5.0$ & - & 0.26 & - & 7 \\
\hline $\begin{array}{l}\text { MWCNT/IL/ } \\
\mathrm{Pd}-\mathrm{NP} / \mathrm{CPE}\end{array}$ & $\begin{array}{c}\mathrm{pH} 4.5 \\
\mathrm{PBS}\end{array}$ & DPV & 180 & $0.1-151$ & $0.6-112$ & 0.03 & 0.2 & 12 \\
\hline $\begin{array}{l}\text { nanoSnO} / \\
\text { MWCNTs/ } \\
\text { CPE } \\
\text { PSNSB/CPE }\end{array}$ & $\begin{array}{c}\mathrm{pH} 6.4 \\
\text { PBS } \\
\text { pH } 4.6\end{array}$ & DPV & 155 & $0.3-50$ & $1000-5000$ & 0.03 & 50 & 13 \\
\hline PSNSB/CPE & $\begin{array}{c}\text { PBS } \\
\text { pH } 7.5\end{array}$ & DPV & 222 & $0.05-1200$ & $2.5-1003$ & 0.02 & 0.18 & 14 \\
\hline AgNPs/CPE & $\begin{array}{c}\text { PBS } \\
\text { pH } 7.0\end{array}$ & DPV & 181 & $1.0-50.0$ & - & 0.08 & - & 16 \\
\hline PQ-CNF/CPE & $\begin{array}{c}\text { PBS } \\
\text { pH } 7.4\end{array}$ & DPV & 244 & $\begin{array}{c}0.5-160 \\
7-70\end{array}$ & $50-4000$ & 0.2 & 15 & 18 \\
\hline $\mathrm{SrPdO}_{3} / \mathrm{CPE}$ & PBS & DPV & 168 & $90-160$ & - & 0.02 & - & 20 \\
\hline $\begin{array}{l}\text { CPE modified with } \\
{[\mathrm{Fe}(\mathrm{II}) \mathrm{TSP}]^{4-}} \\
\mathrm{CPE} \text { modified with }\end{array}$ & $\begin{array}{c}\mathrm{pH} 7.4 \\
\text { PBS }\end{array}$ & $\mathrm{CV}$ & 88 & $1.0-50$ & $0.9-10.0$ & 0.45 & 0.75 & 22 \\
\hline $\begin{array}{l}{\left[\mathrm{Cu}(\mathrm{bp})\left(\mathrm{H}_{2} \mathrm{O}\right)_{2}\right]_{\mathrm{n}}} \\
\text { GCE modified with }\end{array}$ & $\begin{array}{l}\mathrm{pH} 5.0 \\
\text { PBS } \\
\text { pH } 4.0\end{array}$ & DPV & 200 & $0.05-30.0$ & $0.05-30.0$ & 0.04 & 0.02 & 23 \\
\hline $\begin{array}{l}\mathrm{ZnO}-\mathrm{Cu}_{\mathrm{x}} \mathrm{O}-\mathrm{PPy} \\
\mathrm{GCE} \text { modified with }\end{array}$ & $\begin{array}{l}\text { BR solution } \\
\text { pH } 7.0\end{array}$ & DPV & 150 & $0.1-130$ & $0.2-1.0$ & 0.04 & 25.0 & 38 \\
\hline $\begin{array}{l}\gamma-\mathrm{WO}_{3} \\
\left.\text { cis-[Mo }(\mathrm{O})_{2} \mathrm{~L}\right] \text {-modified } \\
\mathrm{CPE} \text { containing } \\
\text { surfactant }\end{array}$ & $\begin{array}{c}\text { PBS } \\
\text { pH } 5.0 \\
0.1 \mathrm{M} \text { acetate buffer }\end{array}$ & DPV & 308 & $2.0-10000.0$ & $3.0-6000.0$ & 0.02 & 0.5 & This work \\
\hline
\end{tabular}

Note: EBT, Eriochrome Black T; CPE, carbon paste electrode; SDS, sodium dodecyl sulphate; RGO, reduced graphene oxide; MWCNTs, multiwalled carbon nanotubes; IL, ionic liquid;Pd-NP, Pd nanoparticle; PSNSB, PbS nanoparticles Schiff base; AgNPs, silver nanoparticles; Pd-CNF/CPE, Palladium nanoparticle-loaded carbon nanofibers; $[\mathrm{Fe}(\mathrm{II}) \mathrm{TSPc}]^{4-}$, ron(II)tetrasulfophthalocyanine; GCE, glassy carbon electrode; $\left[\mathrm{Cu}(\mathrm{bp})\left(\mathrm{H}_{2} \mathrm{O}\right)_{2}\right]_{\mathrm{n}}$, polymer of 4,4'-dicyanamidobiphenyl $\mathrm{Cu}(\mathrm{II})$ complex; PPy, polypyrrole; $\gamma$ - $\mathrm{WO}_{3}$, monoclinic structure of Tungsten trioxide nanoparticles. 


\section{References}

1. H. Zhang, J. Zhang, J. Zheng, Measurement 2015, 59, 177-183. DOI:10.1016/j.measurement.2014.09.044

2. D. M. Stankovi, A. Samphao, B. Dojcinovi, K. Kalcher, Acta Chim. Slov. 2016, 63, 220-226. DOI:10.17344/acsi.2015.1541

3. D. W. Martin Jr., P. A. Mayes, V. W. Rodwell (Eds.), Harper's Review of Biochemistry, 19th ed., Lange, Los Altos, CA, 1983, p. 112.

4. R. M. Wightman, C. Amatorh, R. C. Engstrom, P. D. Hale, E. W. Kristensen, W. G. Kuhr, L. J. May, Neuroscience 1988, 25, 513-523. DOI:10.1016/0306-4522(88)90255-2

5. A. J. Downard, A. D. Roddick, A. M. Bond, Anal. Chim. Acta 1995, 317, 303-310. DOI:10.1016/0003-2670(95)00397-5

6. U. Chandra, B. E. K. Swamy, O. Gilbert, B. S. Sherigara, Int. J. Electrochem. Sci. 2010, 5, 1475-1483.

7. H. Vidya, B. E. K. Swamy, J. Mol. Liq. 2015, 211, 705-711. DOI:10.1016/j.molliq.2015.07.011

8. W. Sun, M. Yang, K. Jiao, Anal. Bioanal. Chem. 2007, 389, 1283-1291. DOI:10.1007/s00216-007-1518-2

9. S. Shahrokhian, M. Ghalkhani, Electrochim. Acta 2006, 51, 2599-2606. DOI:10.1016/j.electacta.2005.08.001

10. S. Shahrokhian, H. R. Zare-Mehrjardi, Electrochim. Acta 2007, 52, 6310-6317. DOI:10.1016/j.electacta.2007.04.023

11. A. A. Abdelwahab, Y.-B. Shim, Sens. Act. B 2015, 221, 659665. DOI:10.1016/j.snb.2015.07.016

12. A. A. Rafati, A. Afraz, A. Hajian, P. Assari, Microchim. Acta 2014, 4, 1293-1297.

13. D. Sun, Q. Zhao, F. Tan, X. Wang, J. Gao, Anal. Methods 2012, 4, 3283-3289. DOI:10.1039/c2ay25401h

14. N. Soltani, N. Tavakkoli, N. Ahmadi, F. Davar, C. R. Chimie 2015, 18(4), 438-448. DOI:10.1016/j.crci.2014.07.001

15. S. Sharafzadeh, A. Nezamzadeh-Ejhieh, Electrochim. Acta 2015, 184, 371-380. DOI:10.1016/j.electacta.2015.09.164

16. H. Vidya, B. E. K. Swamy, M. Schell, J. Mol. Liq. 2016, 214, 298-305. DOI:10.1016/j.molliq.2015.12.025

17. A. K. Bhakta, R. J. Mascarenhas, O. J. D’Souza, A. K. Satpati, S. Detriche, Z. Mekhalif, J. Dalhalle, Mater. Sci. Eng., C 2015, 57, 328-337. DOI:10.1016/j.msec.2015.08.003

18. J. Huang, Y. Liu, H. Hou, T. You, Biosens. Bioelectron. 2008, 24, 632-637. DOI:10.1016/j.bios.2008.06.011

19. S. Sakthinathan, S. Kubendhiran, Sh. M. Chen, K. Manibalan, M. Govindasamy, P. Tamizhdurai, Sh. T. Huang, Electroanalysis 2016, 28, 1-11. DOI:10.1002/elan.201600085

20. N. F. Atta, S. M. Ali, E. H. El-Ads, A. Galal, Electrochim. Acta 2013, 128, 16-24. DOI:10.1016/j.electacta.2013.09.101
21. J. Yang, W. Li, T. Yang, Sh. Hou, Int. J. Electrochem. Sci., 2016, 11, 5691-5701. DOI:10.20964/2016.07.12

22. J. Oni, P. Westbroek, T. Nyokong, Electroanalysis 2003, 15, 847-854. DOI:10.1002/elan.200390104

23. E, Ülker, M. Kavanoz, Acta Chim. Slov. 2016, 63, 47-54.

24. M. K. Amini, S. Shahrokhian, S. Tangestaninejad, V. Mirkhani, Anal. Biochem. 2001, 290, 277-282.

DOI:10.1006/abio.2000.4929

25. S. Shahrokhian, M. Karimi, Electrochim. Acta 2004, 50, 77-84. DOI:10.1016/j.electacta.2004.07.015

26. Y. V. M. Reddy, V. P. Rao, A. V. B. Reddy, M. Lavanya, M. Venu, M. Lavanya, G. Madhavi, Mater. Sci. Eng., C 2015, 57, 378-386. DOI:10.1016/j.msec.2015.08.005

27. S. Shahrokhian, A. Souri, H. Khajehsharifi, J. Electroanal. Chem. 2004,565, 95-101.

DOI:10.1016/j.jelechem.2003.09.039

28. S. Shahrokhian, H. R. Zare-Mehrjardi, Electroanalysis 2007, 19, 2234-2242. DOI:10.1002/elan.200703974

29. W. Liao, C. Guo, L. Sun, Z. Li, L. Tian, J. He, J. Li, J. Zheng, Z. Ma, Z. Luo, C. Chen, Int. J. Electrochem. Sci. 2015, 10, 57475755.

30. K. Chattopadhyay, S. Mazumdar, Bioelectrochem. 2000, 53, 17-24. DOI:10.1016/S0302-4598(00)00092-1

31. H. Kargar, M. N. Tahir, Acta. Cryst. 2012, E68, m1297-m1298.

32. H. Zhao, Y. Zhang, Z. Yuan, Anal. Chim. Acta 2001, 441, $117-$ 122. DOI:10.1016/S0003-2670(01)01086-8

33. E. W. Kristensen, W. G. Kuhr, R. M. Wightman, Anal. Chem. 1987, 59, 1752-1757. DOI:10.1021/ac00141a003

34. L. Yang, N. Huang, Q. Lu, M. Liu, H. Li, Y. Zhang and S. Yao, Anal. Chim. Acta 2016, 903, 69-80.

DOI:10.1016/j.aca.2015.11.021

35. Kh. Ghanbari and N. Hajheidari, Anal. Biochem. 2015, 473, 53-62. DOI:10.1016/j.ab.2014.12.013

36. A. C. Anithaa, N. Lavanya, K. Asokan and C. Sekar, Electrochim. Acta 2015, 167, 294-302.

DOI:10.1016/j.electacta.2015.03.160

37. P. Gunniff (Ed.), Official Methods of Analysis of the Association of Official Analytical Chemists (AOAC), vol. 2, 16th ed., Association of Official Analytical Chemists, Arlington, VA, 1995.

38. Kh. Ghanbari, N. Hajheidari, Anal. Biochem. 2015, 473, 5362. DOI:10.1016/j.ab.2014.12.013

39. A. C. Anithaa, N. Lavanya, K. Asokan, C. Sekar, Electrochim. Acta 2015, 167, 294-302.

DOI:10.1016/j.electacta.2015.03.160

\section{Povzetek}

V tem delu opisujemo cis- $\left[\mathrm{Mo}(\mathrm{O})_{2} \mathrm{~L}\right]$-modificirano elektrodo iz ogljikove paste. Pri optimalnem $\mathrm{pH}(5,0)$ raztopin smo dosegli najboljšo ločbo anodnih vrhov askorbinske kisline in dopamina ter linearno zvezo med anodnim tokom in koncentracijo askorbinske kisline v območju od 3,0 $\times 10^{-6}$ do $6.0 \times 10^{-3} \mathrm{M}$ oziroma koncentracijo dopamina v območju od $2,0 \times 10^{-6}$ do $1,0 \times 10^{-2} \mathrm{M}$. Meja zaznave $(\mathrm{S} / \mathrm{N}=3)$ za dopamin je bila $4 \times 10^{-7} \mathrm{M}$, za askorbinsko kislino pa $5 \times 10^{-7}$ M. Poleg naštetega sta za pripravljeno elektrodo karakteristični še enostavna priprava in regeneracija površine. Opisana elektroda je primerna za sočasno voltametrično določanje dopamina in askorbinske kisline. 